E3S Web of Conferences 1, 15002 (2013)

DOI: $10.1051 / \mathrm{e} 3$ sconf/20130115002

(c) Owned by the authors, published by EDP Sciences, 2013

\title{
Content of heavy metals in the muscle tissue of cattle
}

\author{
$\underline{\text { T.V. Petukhova }}^{1}$ \\ ${ }^{1}$ Novosibirsk State Agrarian University,160 Dobrolubov Str., Novosibirsk 630039, Russia, tapetva@gmail.com
}

\begin{abstract}
Muscle tissue to examine was taken from 31 Black-and-White bull-calves of West Siberia, aged 18 months. The concentration of 11 trace elements in the samples of the muscle tissue was determined with the method of atomic emission spectrometry with inductively associated plasma. The concentration of heavy metals $(\mathrm{mg} / \mathrm{kg})$ in the muscle tissue was equal to: $\mathrm{Pb}-0.070 ; \mathrm{Cd}-0.015 ; \mathrm{As}-0.305 ; \mathrm{Sr}-0.255 ; \mathrm{Rb}-1.458$; $\mathrm{Cu}-1.571 ; \mathrm{Fe}-50.884 ; \mathrm{Zn}-52.99 ; \mathrm{Hg}-0.007 ; \mathrm{Ni}-0.069$. Different correlations were revealed between the concentration of $\mathrm{Cd}$ in muscles and the level of $\mathrm{Cu}$ and $\mathrm{Cr}$ in hair $(\mathrm{r}=-0.349$ and $\mathrm{r}=0.374$, respectively); $\mathrm{Cu}$ in muscles and $\mathrm{Cd}$ in hair $(\mathrm{r}=-0.377), \mathrm{Zn}$ in muscles and $\mathrm{Zn}, \mathrm{Cd}$ in hair $(\mathrm{r}=-0.558$ and $\mathrm{r}=-0.470$, respectively); $\mathrm{Pb}$ in muscles and $\mathrm{Si}$ in hair $(\mathrm{r}=-0.415)$; $\mathrm{Hg}$ in muscles and $\mathrm{Cu}, \mathrm{Cd}$ in hair $(\mathrm{r}=0.449$ and $\mathrm{r}=0.386)$. Correlations were revealed between the level of $\mathrm{Cd}$ in muscles and the concentration of $\mathrm{Ba}, \mathrm{Zn}$ and $\mathrm{P}$ in blood serum $(r=0.574, r=-0.469$ and $r=-0.493$ respectively); between $\mathrm{Pb}$ in muscles and $\mathrm{Fe}$ in serum blood $(\mathrm{r}=$ $0.535)$.
\end{abstract}

Keywords: Heavy metals, cattle, muscle, hair, blood serum.

\section{Introduction}

Chemical elements play one of the major parts in the organism, they are involved in a great many biochemical reactions controlling homeostasis. Changes in their concentration in certain organs can be of diagnostic character when detecting pathological processes. The study of the content of essential microelements $(\mathrm{Zn}, \mathrm{Cu}$, $\mathrm{Fe}$, etc.) in organs and tissues of animals is of great importance. The composition of about 3000 proteins includes $\mathrm{Zn}$ and nearly 1000 proteins are enzymes with catalytic function of $\mathrm{Zn}[1,2]$. Iron $(\mathrm{Fe})$ is an oxygen carrier and its role is great in releasing energy, fermentative reactions, immunity and cholesterol metabolism. There are well-known hereditary disorders such as iron deficiency anemia (IDA), hereditary hemochromatosis [3,4] and other diseases [5]. Copper is a part of many vitamins, hormones, respiratory pigments, myelin sheaths of nerves. The one is involved in metabolism and tissue respiration, it maintains bone and cartilage structures as well as elasticity of blood vessel walls, derma and so on. Copper facilitates Fe absorption. It is proved that accumulation of chemical elements is characteristic of organs and tissues [6]. Hence it is necessary to know the population level of their content in the organism taking into account natural and climatic conditions, species, breed and the period of ontogenesis.

\section{Materials and Methods}

Muscle tissue to examine was taken from 31 Black-andWhite bull-calves of West Siberia, aged 18 months. In Analytical Geochemistry Laboratory of Joint Institute of Geology, Geophysics and Mineralogy of SB RAS, the concentration of 11 trace elements in the samples of the muscle tissue was determined with the method of atomic emission spectrometry with inductively associated plasma. The weight of up to $1 \mathrm{~g}$ was taken from the pooled sample. The weight in a quartz cup was carried onto the oven $\left(\mathrm{T} \sim 150{ }^{\circ} \mathrm{C}\right)$, then, dried for 12 hours to obtain small pieces of coal. The dried weights were placed into a muffle furnace $\left(\mathrm{T} \sim 100^{\circ} \mathrm{C}\right)$ with its door open. Every 30 minutes the temperature was to be up by $50{ }^{\circ} \mathrm{C}$, the furnace temperature reaching $480{ }^{\circ} \mathrm{C}$. The quartz cups containing the samples were added to with 5 $\mathrm{ml}$ of nitric acid and left for 12 hours. Then, the samples were heated to obtain a dry sediment (dross) and the each one was introduced with $1 \mathrm{ml}$ of perchloric acid and $5 \mathrm{ml}$ of nitric acid. $2 \mathrm{ml}$ of scandium were added to each sample, the terminal Sc concentration being $2 \mathrm{mcg} / \mathrm{ml}$ in the solution.

\section{Results and Discussion}

The highest $\mathrm{Zn}$ and Fe content was in muscle tissue (table 1). The concentration of copper was much lower. There are interspecies differences in the content of chemical 
elements in organs and tissues. Thus, eg., the content of $\mathrm{Zn}, \mathrm{Fe}$ and $\mathrm{Cu}$ was much higher in Siberia's Precocious Meat pigs than that in cattle [6,7].

Table 1. Heavy metals concentrations in muscle tissue (mg/kg)

\begin{tabular}{|l|c|c|}
\hline Elements & $-x \quad \pm$ lim & \\
\hline $\mathrm{Zn}$ & $52.99 \pm 1.24$ & $24.59-63.71$ \\
\hline $\mathrm{Fe}$ & $50.88 \pm 2.61$ & $30.30-79.50$ \\
\hline $\mathrm{Cu}$ & $1.571 \pm 0.059$ & $1.10-2.90$ \\
\hline $\mathrm{Ni}$ & $0.069 \pm 0.014$ & $0.010-0.350$ \\
\hline $\mathrm{Co}$ & $0.015 \pm 0.009$ & $0.001-0.089$ \\
\hline $\mathrm{Rb}$ & $1.458 \pm 0.053$ & $0.936-2.473$ \\
\hline $\mathrm{Sr}$ & $0.255 \pm 0.026$ & $0.080-0.650$ \\
\hline $\mathrm{Cd}$ & $0.015 \pm 0.001$ & $0.009-0.036$ \\
\hline $\mathrm{Pb}$ & $0.070 \pm 0.013$ & $0.024-0.200$ \\
\hline $\mathrm{As}$ & $0.305 \pm 0.050$ & $0.000-0.940$ \\
\hline $\mathrm{Hg}$ & $0.007 \pm 0.0009$ & $0.000-0.024$ \\
\hline
\end{tabular}

In muscles, the concentration of $\mathrm{Hg}, \mathrm{Cd}$ and $\mathrm{Co}$ was minor. The highest phenotypic variability was characteristic of $\mathrm{Co}, \mathrm{Pb}, \mathrm{Hg}$ and As.

Correlations between different chemical elements in muscles were studied. High relations were identified between the content of $\mathrm{Cr}$ and $\mathrm{Ca}(\mathrm{r}=0.763)$, $\mathrm{Fe}$ and $\mathrm{Mn}(\mathrm{r}=0.639), \mathrm{Pb}$ and $\mathrm{Cu}(\mathrm{r}=0.564), \mathrm{Cu}$ and $\mathrm{K}$ $(\mathrm{r}=-0.677)$. As and $\mathrm{Cd}(\mathrm{r}=-0.338), \mathrm{Zn}$ and $\mathrm{Ni}(\mathrm{r}=-$ 0.572 ) correlated negatively.

The search for non- and low-invasive markers of HM accumulation tissues is of importance (table 2). The content of $\mathrm{Cd}$ and $\mathrm{Cu}$ in hair correlates to the accumulation of $\mathrm{Hg}$ in muscles $(r=0.386$ and $r=0.449$ respectively). The content of $\mathrm{Si}$ and $\mathrm{K}$ in hair can be the marker of $\mathrm{Pb}$ accumulation in muscles $(\mathrm{r}=-0.415$ and $\mathrm{r}$ $=-0.390$ respectively).

Table 2. Correlation of the content of chemical elements in hair and muscles.

\begin{tabular}{|l|l|l|l|}
\hline \multicolumn{1}{|c|}{$\begin{array}{c}\text { Hair }- \\
\text { muscle }\end{array}$} & \multicolumn{1}{c|}{$\mathrm{r}$} & \multicolumn{1}{c|}{$\begin{array}{c}\text { Hair }- \\
\text { muscle }\end{array}$} & \multicolumn{1}{c|}{$\mathrm{r}$} \\
\hline $\mathrm{B}-\mathrm{Cd}$ & -0.372 & $\mathrm{Al}-\mathrm{Hg}$ & 0.342 \\
\hline $\mathrm{Cr}-\mathrm{Cd}$ & 0.374 & $\mathrm{Cu}-\mathrm{Hg}$ & 0.449 \\
\hline $\mathrm{Cu}-\mathrm{Cd}$ & -0.349 & $\mathrm{Cd}-\mathrm{Hg}$ & 0.386 \\
\hline $\mathrm{K}-\mathrm{Pb}$ & -0.390 & $\mathrm{Cd}-\mathrm{As}$ & -0.413 \\
\hline $\mathrm{Si}-\mathrm{Pb}$ & -0.415 & $\mathrm{Zn}-\mathrm{Fe}$ & 0.330 \\
\hline & & $\mathrm{K}-\mathrm{Rb}$ & 0.419 \\
\hline
\end{tabular}

More closer relations were identified due to the accumulation of heavy metals in muscles and the content of different chemical elements in blood serum (table 3).

Table 3. Correlation of the content of chemical elements in blood serum and muscles

\begin{tabular}{|l|l|l|l|}
\hline $\begin{array}{c}\text { Blood } \\
\text { serum - } \\
\text { muscles }\end{array}$ & \multicolumn{1}{|c|}{$\mathrm{r}$} & \multicolumn{1}{|c|}{$\begin{array}{c}\text { Blood } \\
\text { serum - } \\
\text { muscles }\end{array}$} & \multicolumn{1}{|c|}{$\mathrm{r}$} \\
\hline $\mathrm{Ba}-\mathrm{Cd}$ & 0,574 & $\mathrm{Ba}-\mathrm{Fe}$ & 0,422 \\
\hline $\mathrm{P}-\mathrm{Cd}$ & $-0,483$ & $\mathrm{Cu}-\mathrm{Fe}$ & 0,394 \\
\hline $\mathrm{Rb}-\mathrm{Cd}$ & $-0,416$ & $\mathrm{Rb}-\mathrm{Fe}$ & 0,424 \\
\hline $\mathrm{Zn}-\mathrm{Cd}$ & $-0,469$ & $\mathrm{~B}-\mathrm{Rb}$ & $-0,449$ \\
\hline $\mathrm{Fe}-\mathrm{Sr}$ & 0,348 & $\mathrm{Cl}-\mathrm{Rb}$ & $-0,359$ \\
\hline $\mathrm{Cl}-\mathrm{Pb}$ & 0,449 & $\mathrm{Cu}-\mathrm{Rb}$ & $-0,442$ \\
\hline $\mathrm{Fe}-\mathrm{Pb}$ & 0,535 & $\mathrm{Rb}-\mathrm{As}$ & 0,356 \\
\hline $\mathrm{Rb}-\mathrm{Pb}$ & $-0,453$ & & \\
\hline
\end{tabular}

Correlations of middle value were observed between the content of $\mathrm{Cd}$ in muscles and the concentration of $\mathrm{Ba}, \mathrm{P}, \mathrm{Zn}$ and $\mathrm{Rb}$ in blood serum $(\mathrm{r}=0.574, \mathrm{r}=-0.483, \mathrm{r}=-0.469$ and $\mathrm{r}=-0.416$, respectively). The association of the level of a series of chemical elements in blood serum with that of $\mathrm{Fe}$ and $\mathrm{Rb}$ in muscles was also observed. Thus, the content of some chemical elements in hair and serum can be used as indexes of the content of heavy metals in muscles.

\section{Conclusion}

Mean population levels of the content of heavy metals were determined in the muscles of Black-and-White cattle. Positive and negative relations were revealed in the level of a series of chemical elements in hair and blood serum to the accumulation of heavy metals in the muscle tissue of Black-and-White bulls. The content of a complex of chemical elements in the hair and blood serum can be used as lifetime indicators of HM accumulation in the muscle of cattle.

\section{References}

1. Hajo H., Maret W. The regulatory and signaling functions of $\mathrm{Zn}$ ions in human cellular physiology/ Edited by Zalups R., Koropatnick/ Cellular and Molecular biology of metals. US. CRC Press Taylor\&Francis group. 2010:pp.181-212.

2. Oberles D., Harland B., Skalny A. Biological role macro- and microelements in humans and animals . St-Petersburg: Nauka. 2008. - 544 p.

3. Sebastiani G., Pantopoulos K. Iron metabolism and desease/ Edited by Zalups R., Koropatnick/ Cellular and Molecular biology of metals. US. CPC Press Taylor\&Francis group. 2010: pp.351-378.

4. Pietrangelo A. Hereditary hemochromatosis - a new look at an old disease. N. Engl. J. Med. 350. pp.2383-2397.

5. Trace elements in animal production systems/ 
Edited by Schlegel P., Durosoy S., Jongbloed A.W. Wageningen Academic Publishers. Netherlands. 2008: $347 \mathrm{p}$.

6. Petukhov V.L., Tikhoov V. N., Zheltikov A.I. Gene pools of early ripe meat breed. Novosibirsk. 2005. $631 \mathrm{p}$.
7. Korotkevich O.S., Zheltikova O.A., Petukhov V.L. Biochemical and hematological parameters and heavy metal accumulation in organs and tissues of pigs of the precocious meat breed. Russian Agricultural Sciences. 2009. vol.35. No4. - pp.259-261. 